\title{
Dual-Electronic Nanomaterial (Synthetic Clay) for Effective Removal of Toxic Cationic and Oxyanionic Metal Ions from Water
}

\author{
Van Phuong Nguyen, ${ }^{1,2}$ Khanh Thien Tran Nguyen, ${ }^{3}$ Loc That Ton, ${ }^{4}$ Dong Thanh Nguyen, ${ }^{5}$ \\ Khuong Quoc Nguyen, ${ }^{6}$ Mai Thi Vu, ${ }^{7}$ and Hai Nguyen Tran $\mathbb{D}^{2,8}$ \\ ${ }^{1}$ Institute of Research and Development, Duy Tan University, Danang 550000, Vietnam \\ ${ }^{2}$ Faculty of Environmental and Chemical Engineering, Duy Tan University, Da Nang City, Vietnam \\ ${ }^{3}$ Department of Environment Sustainable Development, An Giang University, An Giang, VNU-HCM, Vietnam \\ ${ }^{4}$ Department of Management Science, Thu Dau Mot University, Binh Duong, Vietnam \\ ${ }^{5}$ Institute of Environmental Technology, Vietnam Academy of Science and Technology, Hanoi, Vietnam \\ ${ }^{6}$ Department of Crop Science, College of Agriculture, Can Tho University, Can Tho, Vietnam \\ ${ }^{7}$ Hanoi University of Natural Resources and Environment, Ministry of Natural Resources and Environment, Hanoi, Vietnam \\ ${ }^{8}$ Institute of Fundamental and Applied Sciences, Duy Tan University, Ho Chi Minh City, Vietnam
}

Correspondence should be addressed to Hai Nguyen Tran; trannguyenhai@duytan.edu.vn

Received 1 February 2020; Revised 30 March 2020; Accepted 21 May 2020; Published 7 September 2020

Academic Editor: Laura Martinez Maestro

Copyright (c) 2020 Van Phuong Nguyen et al. This is an open access article distributed under the Creative Commons Attribution License, which permits unrestricted use, distribution, and reproduction in any medium, provided the original work is properly cited.

A synthetic clay (Mg/Al-layered double hydroxides; $\mathrm{LDH})$ was directly synthesized through a simple coprecipitation method under a low-supersaturation condition. The clay was applied to remove metal cations $\left(\mathrm{Cd}^{2+}, \mathrm{Cu}^{2+}, \mathrm{Pb}^{2+}, \mathrm{Ni}^{2+}\right.$, and $\left.\mathrm{Cr}^{3+}\right)$ and oxyanions $\left(\mathrm{MnO}_{4}^{-}\right.$and $\left.\mathrm{Cr}_{2} \mathrm{O}_{7}{ }^{2-}\right)$ from a single aqueous solution. The result demonstrated that LDH exhibited a poor porosity (its specific surface area and total pore volume: $23.2 \mathrm{~m}^{2} / \mathrm{g}$ and $0.161 \mathrm{~cm}^{3} / \mathrm{g}$, respectively) and positively charged surface within solution $\mathrm{pH}$ from 3.0 to 12. The X-ray powder diffraction (XRD) data suggested that the basal spacing of LDH was $0.773 \mathrm{~nm}$. The presence of active $\mathrm{CO}_{3}{ }^{2-}$ anions in the interlayer region of $\mathrm{LDH}$ that played an extremely important role in the adsorption process was identified by XRD and Fourier-transform infrared spectroscopy (FTIR). Energy-dispersive X-ray spectroscopy (SEM) analysis indicated that $\mathrm{LDH}$ possessed a surface morphology like a plate with a hexagonal shape. The adsorption isotherms of LDH towards various potentially toxic metals were conducted at $1.0 \mathrm{~g} / \mathrm{L}, \mathrm{pH}_{\mathrm{Equilibrium}} 5.0,30^{\circ} \mathrm{C}$, and $24 \mathrm{~h}$. The Langmuir maximum adsorption capacity of $\mathrm{LDH}$ towards the target metals exhibited the following order: $1.299 \mathrm{mmol} / \mathrm{g}\left(\right.$ for $\mathrm{Ni}^{2+}$ adsorption $)>0.880 \mathrm{mmol} / \mathrm{g} \quad\left(\mathrm{Cd}^{2+}\right)>0.701 \mathrm{mmol} / \mathrm{g} \quad\left(\mathrm{Cr}^{3+}\right)>0.657 \mathrm{mmol} / \mathrm{g} \quad\left(\mathrm{Pb}^{2+}\right)>0.601 \mathrm{mmol} / \mathrm{g} \quad\left(\mathrm{Cu}^{2+}\right)>0.589 \mathrm{mmol} / \mathrm{g}$ $\left(\mathrm{Cr}_{2} \mathrm{O}_{7}{ }^{2-}\right)>0.522 \mathrm{mmol} / \mathrm{g}\left(\mathrm{MnO}_{4}^{-}\right)$. The synthetic clay can adsorb both cations and anions in the solution. Therefore, such $\mathrm{LDH}$ material can serve as a potential dual-electronic adsorbent for effectively eliminating various oxyanionic and cationic metal ions from water media.

\section{Introduction}

The appearance of potentially toxic metals in water bodies has caused more enormous concerns such as potential health risks for humans and environmental threats because of their high toxicity. In real wastewater, anionic and cationic contaminants always coexist in such environment. Therefore, it is necessary to explore and develop some advanced adsorbents with their excellent adsorption capacity towards various kinds of toxic contaminants, although commercial activated carbon (CAC) with its extremely high porosity has been acknowledged as a potential adsorbent for removing various contaminants from a water environment through pore-filling adsorption mechanism [1]. However, CAC, which is a high energy-consuming material, is expensive $(\sim 3 \mathrm{USD} / \mathrm{kg})$ because it is often prepared through 
a pyrolysis process at high temperatures $\left(>800^{\circ} \mathrm{C}\right)$ along with certain activation (i.e., physical or chemical) [2, 3]. Furthermore, an adsorption process related to pore-filling mechanism is usually irreversible for the adsorption of organic contaminants with a large molecule size (i.e., dye). Therefore, contaminant-laden AC cannot be effectively used for regeneration [2]. For example, Tran et al. [3] investigated the adsorption process of cation methylene green dye onto three kinds of AC material. They found that desorption efficiency was negligible when a chemical desorption method was used. In addition, Tomul et al. [4] concluded that the desorption of naproxen from three laden biochar samples by a chemical method was less efficient than that by a thermal method. However, the mass loss during the thermal method should be considered, such as approximately $13 \% \pm 2.5,17 \% \pm 7.4,34 \% \pm 8.4$, and $41 \% \pm 0.95$ for each cycle of adsorption/desorption.

In general, layered double hydroxides (LDH) are normally known as hydrotalcite-like minerals/solids or synthetic anionic clays. The structure of $\mathrm{LDH}$ is composed of two oppositely charged parts: (1) the positively charged brucitelike sheets and (2) negatively charged anionic interlayers [5, 6]. The general formula of $\mathrm{LDH}$ is often expressed as $\left[\mathrm{M}^{2+}{ }_{1-x} \mathrm{M}^{3+}{ }_{x}(\mathrm{OH})_{2}\right]^{x+}\left(\mathrm{A}^{n-}\right)_{x / n} \cdot \mathrm{mH}_{2} \mathrm{O}$ [6]. In this formula, $\mathrm{M}^{2+}$ represents the divalent metal cations (i.e., $\mathrm{Mg}^{2+}$ ), $\mathrm{M}^{3+}$ the trivalent metal cations (i.e., $\mathrm{Al}^{3+}$ ), $\mathrm{A}^{n-}$ the interlayer charge-balancing anions of valence $n$ (i.e., $\mathrm{CO}_{3}{ }^{2-}$ ), and $x$ the $\mathrm{M}^{3+} /\left(\mathrm{M}^{2+}+\mathrm{M}^{3+}\right)$ molar ratio (ranging from 0.20 to $0.33)[6,7]$. According to the literature, LDH has been successfully synthesized by numerous methods (i.e., coprecipitation, ion exchange, hydrothermal method, and rehydration using a structural memory effect) [8]. Of those methods, coprecipitation prepared at a low supersaturation has been considered the most appropriate method for synthesizing LDH because of its simplicity in generating LDH with a high crystalline structure $[6,9]$. The resultant LDH precipitates can be classified as a typical nanomaterial, with their size distribution being approximately $270 \mathrm{~nm}$ for Ni/Fe-LDH [10], $370 \mathrm{~nm}$ for $\mathrm{Zn} / \mathrm{Al}-\mathrm{LDH}$ [11], and $469 \mathrm{~nm}$ for glycerolmodified Ni/Fe-LDH [10].

The structural and morphological characteristics of $\mathrm{LDH}$ are strongly dependent on the synthesis process and the nature of used metal salts [10-12]. For example, LDH is synthesized from metal salts of nitrate (i.e., $\left.\mathrm{Al}\left(\mathrm{NO}_{3}\right)_{3}\right)$; the interlayer region of $\mathrm{LDH}$ often contains the $\mathrm{NO}_{3}{ }^{2-}$ anions [6]. In addition, during the coprecipitation process of metal salts, $\mathrm{CO}_{3}{ }^{2-}$ anions can be performed in the interlayer region of $\mathrm{LDH}$ because $\mathrm{CO}_{2}$ gas is commonly dissolved in water. The presence of $\mathrm{CO}_{3}{ }^{2-}$ anions in such region can be minimized if nitrogen gas flow is sufficiently used during coprecipitation to prevent the existence of $\mathrm{CO}_{3}{ }^{2-}$ anions in solution. However, some previous studies demonstrated that the presence of host anions (i.e., $\mathrm{CO}_{3}{ }^{2-}$ ) in the interlayer region can serve as active exchangeable sites for removing various contaminant anions from water. Such anions comprise (1) inorganic contaminants: hexavalent chromium anion (i.e., $\mathrm{CrO}_{4}{ }^{2-}$ and $\left.\mathrm{Cr}_{2} \mathrm{O}_{7}{ }^{2-}\right)[10,12-14]$, arsenate anion $\left(\mathrm{H}_{2} \mathrm{AsO}_{4}{ }^{-}\right.$and $\left.\mathrm{HAsO}_{4}{ }^{2-}\right)[12,15,16]$, and antimonate anion $\left(\mathrm{Sb}(\mathrm{OH})_{6}{ }^{-}\right)$ [15] as well as (2) organic contaminants: anionic reactive blue
21 dye [17], anionic methyl orange dye [18], three other anionic dyes (i.e., Congo red, indigo carmine, and sunset yellow FCF) [19], and anticancerous drug methotrexate [11]. Furthermore, the important role of $\mathrm{CO}_{3}{ }^{2-}$ anions in the interlayer region in effectively removing potentially toxic metals from water through precipitation mechanism (i.e. $\mathrm{CdCO}_{3}$ ) has been acknowledged in the literature. Such cationic metals include $\mathrm{Cu}^{2+}[9,20-22], \mathrm{Zn}^{2+}[20,22,23], \mathrm{Pb}^{2+}[14,22-24]$, $\mathrm{Cd}^{2+}[9,23], \mathrm{Ni}^{2+}[9]$, and $\mathrm{Eu}^{3+}[21]$. To sum up, LDH can be classified as a "dual-electronic adsorbent" because of its unique structure characterization: positively charged sites on its external surface (high positively $\zeta$ potential value) and abundantly exchangeable anions within its interlayer region (high anion exchange capacity).

Recently, some authors developed LDH modified with anionic surfactant sodium dodecyl sulfate (SDS) [18]. The resultant hierarchical flower-like LDH exhibited a hydrophobic surface with a high-water contact angle of $90.1^{\circ}$. Such LDH solid can be classified as an "amphiphilic adsorbent" to remove both polar and nonpolar organic compounds (i.e., anionic methyl orange dye and naphthalene) through adsorption and partition processes, respectively. However, the term of amphiphilic adsorbent is only for LDH modified with a certain anionic surfactant, not for pristine LDH (without any additional modification or treatment).

Furthermore, previous research indicated that $\mathrm{Ca} / \mathrm{Al}-$ $\mathrm{LDH}$ can effectively remove chemical oxygen demand (COD; 73.9\%), UV254 (85.8\%), and total organic carbon (TOC; 74.7\%) from water [25]. The authors [25] also found that COD removal by the $\mathrm{LDH}$ material $(73.9 \%)$ was higher than that by the ion exchange resin (only 60\%). Notably, Rahman and colleagues [22] compared sludge volume formed during the removal process of heavy metals using $\mathrm{Mg} / \mathrm{Al}$ $\mathrm{LDH}$ and $\mathrm{Ca}(\mathrm{OH})_{2}$. They found that using $\mathrm{Mg} / \mathrm{Al}-\mathrm{LDH}$ for removing heavy metals only produced almost half as much sludge as using $\mathrm{Ca}(\mathrm{OH})_{2}$. A similar trend of sludge reduction was obtained when comparing the application of $\mathrm{Mg} / \mathrm{Al}$ $\mathrm{LDH}$ and $\mathrm{Ca}(\mathrm{OH})_{2}$ in treating the acidic mine wastewater [16]. Therefore, application of $\mathrm{LDH}$ for water treatment can minimize the major problems regarding sludge disposal.

In essence, each adsorbent material often exhibits an excellent affinity to each type of pollutant (i.e., cationic or anionic adsorbate). To tackle such problem, a dual-electronic material is developed by applying several further processes (i.e., modification, treatment, or grafting). After those processes, the dual-electronic material can simultaneously remove both cationic and anionic pollutants from the water environment. For example, Chao and Chen [26] prepared hexadecyltrimethylammonium bromide-(HDTMA-) modified NaY zeolite, concluding that this dual-electronic material can well adsorb both cationic $\left(\mathrm{Cu}^{2+}, \mathrm{Zn}^{2+}, \mathrm{Ni}^{2+}, \mathrm{Pb}^{2+}\right.$, and $\left.\mathrm{Cd}^{2+}\right)$ and oxyanionic metal $\left(\mathrm{Cr}_{2} \mathrm{O}_{7}{ }^{2-}\right.$ and $\left.\mathrm{MnO}_{4}^{-}\right)$ions in solution. An analogous conclusion was found for other materials-titanate nanotubes modified with hexadecyltrimethylammonium [27] and mesoporous silicas functionalized with amine and nitrilotriacetic acid anhydride [28].

Layered double hydroxides without further modification or treatment process are highly expected to remove both cationic and oxyanionic metal ions from solution through their 


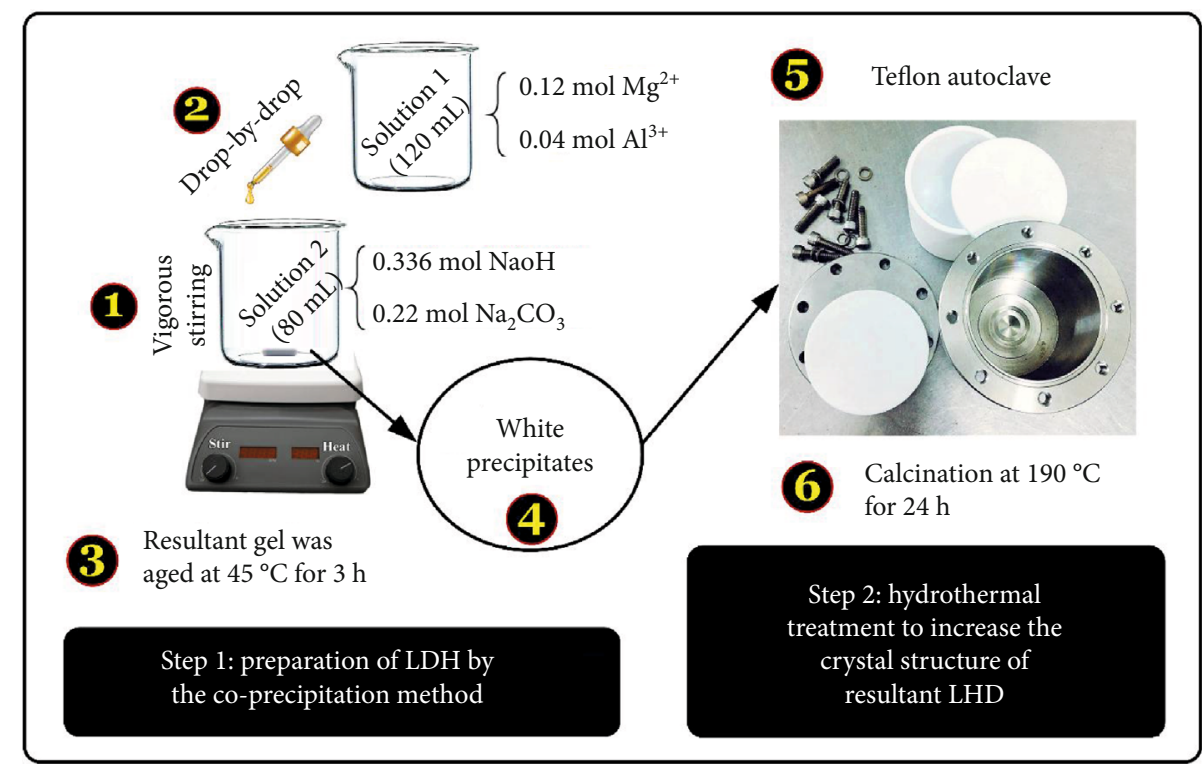

FIGURE 1: Producer for preparation of Mg/Al-layered double hydroxides by the coprecipitation process.

unique properties. Therefore, in this study, a dual-electronic nanomaterial derived from layered double hydroxides was directly synthesized by a simple coprecipitation method. A hydrothermal treatment was subsequently used to further improve the crystalline structure of LDH. The synthesized nanomaterial was characterized by textual property, surface morphology and functionality, zeta potential, and crystalline structure. It was then applied as a potential adsorbent to adsorb five cationic metals $\left(\mathrm{Cd}^{2+}, \mathrm{Cu}^{2+}, \mathrm{Pb}^{2+}, \mathrm{Ni}^{2+}\right.$, and $\left.\mathrm{Cr}^{3+}\right)$ and two oxyanion metals $\left(\mathrm{MnO}_{4}{ }^{-}\right.$and $\left.\mathrm{Cr}_{2} \mathrm{O}_{7}{ }^{2-}\right)$ in single aqueous solution. The relevant adsorption mechanism was also discussed herein.

\section{Material and Method}

2.1. Chemicals. Whole chemicals used in this investigation were of analytical reagent grade, so they were directly used without any further purification. Aluminum nitrate 9hydrate and magnesium nitrate hexahydrate were bought from Merck. Sodium carbonate and sodium hydroxide puriss were purchased from BAKER. Four selective divalent cation metals include cadmium nitrate tetrahydrate (purchased from Alfa Aesar), nickel(II) nitrate hexahydrate (Merch), copper(II) nitrate trihydrate (Merch), and lea$\mathrm{d}(\mathrm{II})$ nitrate (Sigma-Aldrich). One trivalent cation metal (chromium(III) nitrate nonahydrate) was delivered from Merch. Meanwhile, two oxyanionic metal ions-potassium permanganate and potassium dichromate-were selected from Sigma-Aldrich and Merch, respectively. Deionized distilled high-purity water was obtained from a Milli-Q water (Millipore) system.

2.2. Preparation of Layered Double Hydroxides. The Mg/Al$\mathrm{LDH}$ nanoparticles were synthesized through a two-step process: coprecipitation and thermal crystallization [29]. Briefly, the mixture solution of $\mathrm{Mg}\left(\mathrm{NO}_{3}\right)_{2} \cdot 6 \mathrm{H}_{2} \mathrm{O}$ and $\mathrm{Al}\left(\mathrm{NO}_{3}\right)_{3} \cdot 9 \mathrm{H}_{2} \mathrm{O}$ was added dropwise into another $(\mathrm{NaOH}$ and $\left.\mathrm{Na}_{2} \mathrm{CO}_{3}\right)$ under stirring. The $\mathrm{pH}$ of the solution was controlled at approximately $12 \pm 0.3$ for $3 \mathrm{~h}$ at $45^{\circ} \mathrm{C}$ to obtain white precipitates. Notably, nitrogen gas was not used during the precipitation process to expect the spontaneous formation of abundant $\mathrm{CO}_{3}{ }^{2-}$ anions in the interlayer region of $\mathrm{LDH}$. Subsequently, the solution containing the precipitates was transferred into a Teflon-lined autoclave. The autoclave was then heated at $190^{\circ} \mathrm{C}$ for $24 \mathrm{~h}$ (Figure 1). The resultant nanoparticles were collected by centrifugation, washed repeatedly with pure water, dried at $60^{\circ} \mathrm{C}$ for $48 \mathrm{~h}$, and stored in a desiccator until further use. A primary test was conducted to explore the effect of $\mathrm{Mg} / \mathrm{Al}$ molar ratios (i.e., $1: 1,2: 1,3: 1,4: 1$, and $5: 1$ ) on the adsorption capacity of LDH to the selective metals. The adsorption results in Figure 2 indicated that an increase in the $\mathrm{Mg} / \mathrm{Al}$ ratio from $1: 1$ to $3: 1$ resulted in increasing the adsorption capacity of $\mathrm{LDH}$ to $\mathrm{Ni}^{2+}$ and $\mathrm{Cr}_{2} \mathrm{O}_{7}^{2-}$ ions in a single solution. However, a further increase in the ratio to $5: 1$ caused a significant decrease in the adsorption capacity of the LDH towards $\mathrm{Ni}$ (II) cation or an insignificant change of the adsorption capacity of the $\mathrm{LDH}$ towards $\mathrm{Cr}(\mathrm{VI})$ anion. Therefore, the molar ratio of $\mathrm{M}^{2+}$ to $\mathrm{M}^{3+}$ of 3:1 was selected for further studies of the characterization of LDH and the adsorption of potentially toxic metals in solution.

2.3. Characterization of Layered Double Hydroxides. X-ray diffraction (XRD) data were obtained from a PANalytical PW3040/60 X'Pert Pro. Fourier-transform infrared (FT-IR) spectrum was detected by a PerkinElmer 1600 FT-IR spectrophotometer. A scanning electron microscope (SEM, S$3000 \mathrm{~N}$, Hitachi) was used to measure the morphological surface property of LDH. The external surface charge of $\mathrm{LDH}$ was analyzed by a zeta potential analyzer (Colloidal Dynamics; ZED-3600). The porosity of LDH was calculated from the nitrogen adsorption/desorption isotherm (Micromeritics ASAP 2020 sorptometer) at $77 \mathrm{~K}$. The LDH sample had been 

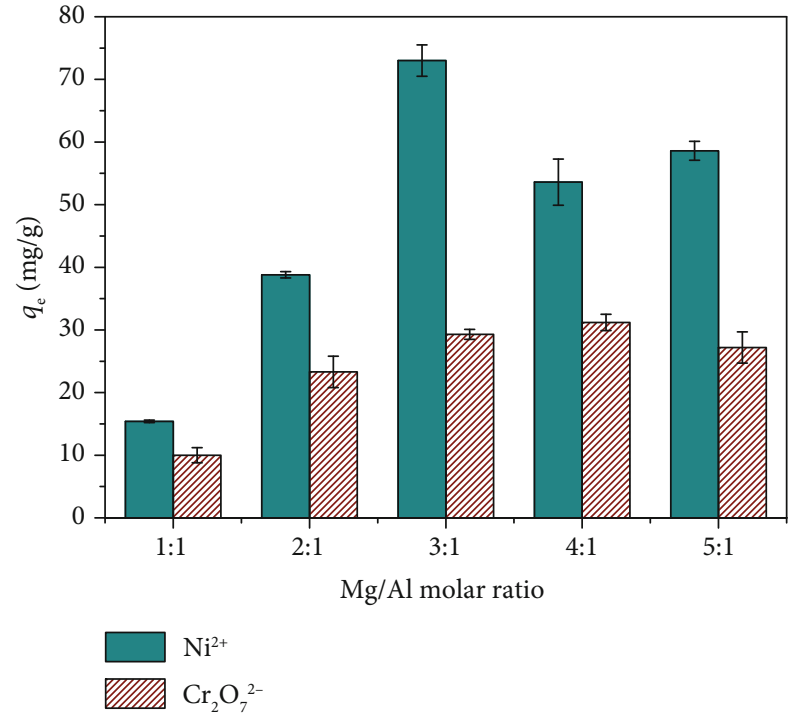

FIGURE 2: Effect of the $\mathrm{Mg} / \mathrm{Al}$ molar ratio on the adsorption capacity of LDH (experimental conditions: $C_{\mathrm{o}}=188 \mathrm{mg} / \mathrm{g}$ for $\mathrm{Ni}$ and $191 \mathrm{mg} / \mathrm{L}$ for $\mathrm{Cr}(\mathrm{VI}), \mathrm{pH}=5.0,24 \mathrm{~h}$, and $30^{\circ} \mathrm{C}$ ).

dried in a vacuum oven at $105^{\circ} \mathrm{C}$ for $24 \mathrm{~h}$ before it was used for analyzing its aforementioned properties.

2.4. Study of Adsorption Isotherm. The study of adsorption isotherm was concluded in a single metal solution to avoid the phenomenon of competitive adsorption. Adsorption conditions were described as follows: a solid/liquid ratio of $1.0 \mathrm{~g} / \mathrm{L}(\mathrm{m} / \mathrm{V})$, temperature of $30^{\circ} \mathrm{C}$, contact time of $48 \mathrm{~h}$, and controlled solution $\mathrm{pH}$ of 5.0. The concentration of toxic metal ions before and after adsorption was determined by an Inductively coupled plasma mass spectrometry (ICPMSNexION 2000, US). The blank sample (the initial concentration of adsorbate without the presence of LDH denoted as the $C_{\mathrm{o}}$ value) was conducted simultaneously. The amount of metal adsorbed by $\operatorname{LDH}\left(q_{\mathrm{e}} ; \mathrm{mmol} / \mathrm{g}\right)$ was calculated from the mass balance equation (Equation (1)). Each study of adsorption was conducted in triplicate, and the average values were reported.

In this study, the Langmuir model (Equation (2)) [30] was applied to estimate the maximum adsorption capacity of LDH towards each target metal. Meanwhile, the Freundlich model [31] (Equation (3)) is commonly used for the real design of water system because it is an empirical equation. Two adsorption isotherm models have been widely applied in the literature to model the experimental data of adsorption equilibrium because of the help of their parameters $[3,5,7,32,33]$. The important role of the parameters of two selective models in the adsorption process was discussed in Section 3.2.

$$
\begin{aligned}
& q_{\mathrm{e}}=\frac{\left(C_{\mathrm{o}}-C_{\mathrm{e}}\right)}{m} V, \\
& q_{\mathrm{e}}=\frac{\left(Q_{\mathrm{max}}^{\mathrm{o}} K_{\mathrm{L}} C_{\mathrm{e}}\right)}{1+K_{\mathrm{L}} C_{\mathrm{e}}},
\end{aligned}
$$

$$
q_{\mathrm{e}}=\left(K_{F} \times C_{\mathrm{e}}^{\mathrm{n}}\right),
$$

where $C_{\mathrm{o}}$ and $C_{\mathrm{e}}(\mathrm{mmol} / \mathrm{L})$ are the concentrations of metal in solution before and after equilibrium adsorption, respectively; $m(\mathrm{~g})$ is the mass of used $\mathrm{LDH} ; V(\mathrm{~L})$ is the volume of the metal solution; $Q_{\max }^{\mathrm{O}}(\mathrm{mmol} / \mathrm{g})$ is the maximum saturated adsorption capacity of $\mathrm{LDH} ; K_{\mathrm{L}}$ $(\mathrm{L} / \mathrm{mmol})$ is the Langmuir constant related to the affinity between metal and $\mathrm{LDH} ; K_{\mathrm{F}}\left[(\mathrm{mmol} / \mathrm{g}) /(\mathrm{L} / \mathrm{mmol})^{n}\right]$ is the Freundlich constant, which characterizes the strength of adsorption; and $n$ (dimensionless; $0<n<1$ ) is a Freundlich intensity parameter, which indicates the magnitude of the adsorption driving force or surface heterogeneity; the adsorption isotherm becomes linear with $n=1$, favorable with $n<1$, and unfavorable with $n>1$.

To minimize error functions during modeling, a nonlinear optimization technique was applied for computing the relevant parameters of the selective models [32]. The adjusted coefficient of determination (Adj- $\left.R^{2}\right)$ and chisquare test $\left(\chi^{2}\right)$ were automatically calculated from the Origin software; meanwhile, standard deviation of residues (SD), Marquardt's percent standard deviation (MPSD) [34], and Bayesian information criterion (BIC) [35] are expressed in Equation (4), (5), and (6), respectively. The best fitting model exhibits the highest $\mathrm{Adj}-R^{2}$ value, but the lowest value of the others (i.e., $\chi^{2}, \mathrm{SD}, \mathrm{MPSD}$, and BIC).

$$
\begin{gathered}
\mathrm{SD}=\sqrt{\left(\frac{1}{n-p}\right)\left[\sum\left(q_{\mathrm{e}, \mathrm{exp}}-q_{\mathrm{e}, \text { model }}\right)^{2}\right]}, \\
\mathrm{MPSD}=100 \sqrt{\left(\frac{1}{n-p}\right)\left[\sum\left(\frac{q_{\mathrm{e}, \mathrm{exp}}-q_{\mathrm{e}, \text { model }}}{q_{\mathrm{e}, \mathrm{exp}}}\right)^{2}\right]}, \\
\mathrm{BIC}=n \ln \left[\frac{\sum\left(q_{\mathrm{e}, \text { exp }}-q_{\mathrm{e}, \text { model }}\right)^{2}}{n}\right]+[p \ln (n)],
\end{gathered}
$$

where $q_{\mathrm{e}, \exp }$ is the amount of adsorbate in solution adsorbed by adsorbent from the experiment (calculated from Equation (1)); $q_{\mathrm{e} \text {,model }}$ is the amount of adsorbate in solution adsorbed by adsorbent estimated from the selective model; $n$ is the number of experimental points used for modelling; and $p$ is the number of parameters in the selective model.

\section{Results and Discussion}

3.1. Property of Layered Double Hydroxides. The structure feature of $\mathrm{LDH}$ was confirmed by the XRD spectrum (Figure 3). As expected, the synthesized LDH was a typically well-crystallized material. Two shaped diffraction peaks observed at two-theta degree of $11.44^{\circ}$ (a typical 003 characteristic) and $22.82^{\circ}(006)$ were consistent with the standard JCPDS file of the hydrotalcite structure (JCPDS No. 890460) and in the literature $[12,36]$. According to the Bragg's law, the basal spacing $\left(d_{003}\right)$ of $\mathrm{LDH}$ was calculated to be $0.773 \mathrm{~nm}$. An identical result was reported for similar 


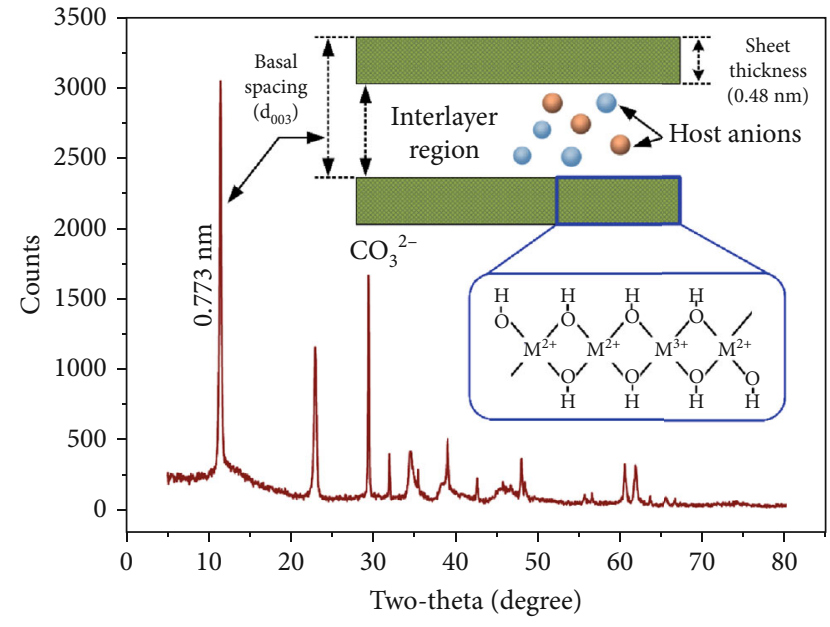

Figure 3: X-ray powder diffraction of the layered double hydroxides.

$\mathrm{Mg} / \mathrm{Al}-\mathrm{LDH}$ materials (i.e., $0.80 \mathrm{~nm}$ [22], $0.780 \mathrm{~nm}$ [15], $0.769 \mathrm{~nm}$ [19], $0.762 \mathrm{~nm}$ [37], $0.760 \mathrm{~nm}$ [14], and $0.758 \mathrm{~nm}$ [12]) and for the other LDH (Zn/Al-LDH $(0.887 \mathrm{~nm})$ [11], $\mathrm{Ni} / \mathrm{Fe}-\mathrm{LDH}(0.782 \mathrm{~nm})$ [10], Mn/Mg/Fe-LDH $(0.777 \mathrm{~nm})$ [24], and $\mathrm{Zn} / \mathrm{Al}-\mathrm{LDH}(0.755 \mathrm{~nm})$ [17]). In addition, because the host $\mathrm{CO}_{3}{ }^{2-}$ anions were abundantly presented in the interlayer region of $\mathrm{LDH}$ (confirming by the XRD spectrum at $29.39^{\circ}$ ), the synthesized nanoparticles can be classified as $\mathrm{LDH}$ containing the interlayer carbonate anions $\left(\mathrm{CO}_{3^{-}}\right.$ LDH). The carbonate anions can (1) effectively interact with selective cationic metals (i.e., cadmium) in solution to form the metal-carbonate precipitation [5] or (2) provide the exchangeable anion sites towards oxyanionic metals (i.e., dichromate) in solution [6, 7].

The isotherm of nitrogen gas adsorption/desorption onto $\mathrm{LDH}$ is illustrated in Figure 4. According to the report of physisorption data for gas/solid systems published by IUPAC [38], the physisorption exhibited a typical characteristic feature of Type IV isotherm, with a type $\mathrm{H} 3$ hysteresis loop being observed at a relative pressure $\left(p / p_{0}\right)$ higher than 0.8 [19]. The IV-type isotherm combined with H3-type loop was an indication of mesoporosity with slit-shaped pores $[6,10,18]$. An analogous observation has been reported elsewhere $[12,36]$. Furthermore, the textural property of $\mathrm{LDH}$ (Table 1) obtained from the physisorption isotherm indicated that $\mathrm{LDH}$ was a nonporous material. This is because it exhibited a low Brunauer-Emmett-Teller (BET) surface area $\left(S_{\mathrm{BET}}=23.2 \mathrm{~m}^{2} / \mathrm{g}\right)$ and total pore volume $\left(V_{\text {Total }}=0.161 \mathrm{~cm}^{3}\right)$. Similarly, some scholars reported that LDH solids exhibited a low specific surface area and total pore volume, such as $\mathrm{Mg} / \mathrm{Al}-\mathrm{LDH}\left(S_{\mathrm{BET}}=51.0 \mathrm{~m}^{2} / \mathrm{g}\right.$ and $V_{\text {Total }}=$ $\left.0.236 \mathrm{~cm}^{3} / \mathrm{g}\right)$ [19], Ni/Fe-LDH $\left(34.2 \mathrm{~m}^{2} / \mathrm{g}\right.$ and $\left.0.06 \mathrm{~cm}^{3} / \mathrm{g}\right)$ [10], Mg/Al-LDH $\left(15.7 \mathrm{~m}^{2} / \mathrm{g}\right.$ and $\left.0.078 \mathrm{~cm}^{3} / \mathrm{g}\right)$ [37], and hierarchical flower-like $\mathrm{Mg} / \mathrm{Al}-\mathrm{LDH}\left(3.58 \mathrm{~m}^{2} / \mathrm{g}\right.$ and $\left.0.076 \mathrm{~cm}^{3} / \mathrm{g}\right)$ [18]. This means that the adsorption of selective metals through well-known pore-filing mechanism seems negligible [6]. In this case, LDH can remove potentially toxic metals from water media through other adsorption mechanisms (e.g., surface precipitation, complexation, and ion exchange).

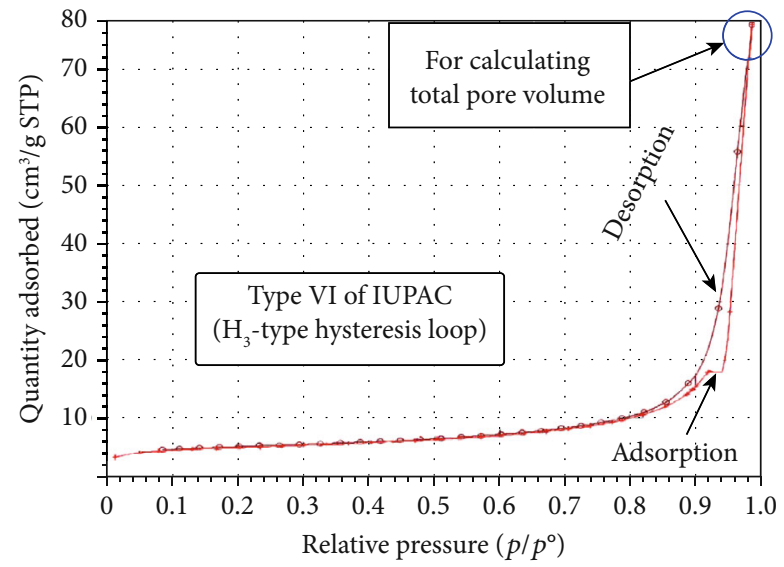

FIGURE 4: Nitrogen gas adsorption/desorption isotherm onto LDH at $77 \mathrm{~K}$.

TABLE 1: Textural parameters of the prepared LDH nanoparticles.

\begin{tabular}{lcc}
\hline & Unit & Value \\
\hline (1) Surface area & & \\
Langmuir surface area & $\mathrm{m}^{2} / \mathrm{g}$ & 119 \\
BET surface area & $\mathrm{m}^{2} / \mathrm{g}$ & 23.2 \\
External surface area & $\mathrm{m}^{2} / \mathrm{g}$ & 15.2 \\
Micropore surface area & $\mathrm{m}^{2} / \mathrm{g}$ & 8.05 \\
(2) Pore volume & & \\
Total pore volume & $\mathrm{cm}^{3} / \mathrm{g}$ & 0.161 \\
Mesopore volume & $\mathrm{cm}^{3} / \mathrm{g}$ & 0.157 \\
Micropore volume & $\mathrm{cm}^{3} / \mathrm{g}$ & 0.004 \\
(3) Pore width & & \\
Average pore width & $\mathrm{nm}$ & 27.8 \\
\hline
\end{tabular}

The main functional groups on the LDH's surface were qualitatively detected by FTIR (Figure 5). Several corresponding key bands were highlighted and provided in the FTIR spectrum. Firstly, a broad band at approximately $3500 \mathrm{~cm}^{-1}$ is designated to the -OH group of the hydroxide layers, interlayer water molecules, and even moisture. Secondly, a profound band at nearly $1640 \mathrm{~cm}^{-1}$ is assigned to the $\mathrm{C}=\mathrm{O}$ overlapped $\mathrm{N}=\mathrm{O}$ functional groups in the interlayer region that might mainly correspond to the interlayer $\mathrm{CO}_{3}{ }^{2-}$ and $\mathrm{NO}_{3}{ }^{-}$anions, respectively. Thirdly, the overlapping of $\mathrm{C}-\mathrm{O}$ (relative to host $\mathrm{CO}_{3}{ }^{2-}$ anion) and $\mathrm{N}-\mathrm{O}$ (host $\mathrm{NO}_{3}{ }^{-}$ anion) vibration is well-identified at around $1370 \mathrm{~cm}^{-1}$. Lastly, two bands corresponding to the metals $(\mathrm{M}=\mathrm{Mg}$ and $\mathrm{Al}$ ) vibrations are observed at approximately $676 \mathrm{~cm}^{-1}(\mathrm{O}-$ $\mathrm{M}-\mathrm{O})$ and $420 \mathrm{~cm}^{-1}(\mathrm{M}-\mathrm{OH})[6,12,36,37,39]$. The result suggested that (1) LDH might contain the abundant host anions $\left(\mathrm{CO}_{3}{ }^{2-}\right.$ and $\left.\mathrm{NO}_{3}{ }^{-}\right)$in the interlayer region and (2) the external surface of LDH might be positively charged because of the abundant presence of $-\mathrm{OH}$ groups (primarily derived from $\mathrm{Al}-\mathrm{OH}$ and $\mathrm{Mg}-\mathrm{OH}$ ) on its surface.

In essence, the $\mathrm{pKa}$ value of the hydroxyl group is often higher than 11 [40]. Therefore, the $-\mathrm{OH}$ group is protonated into the $-\mathrm{OH}_{2}^{+}$group when solution $\mathrm{pH}<$ its $\mathrm{pK}$ a value. This is well consistent with the analysis result of zeta potential of 


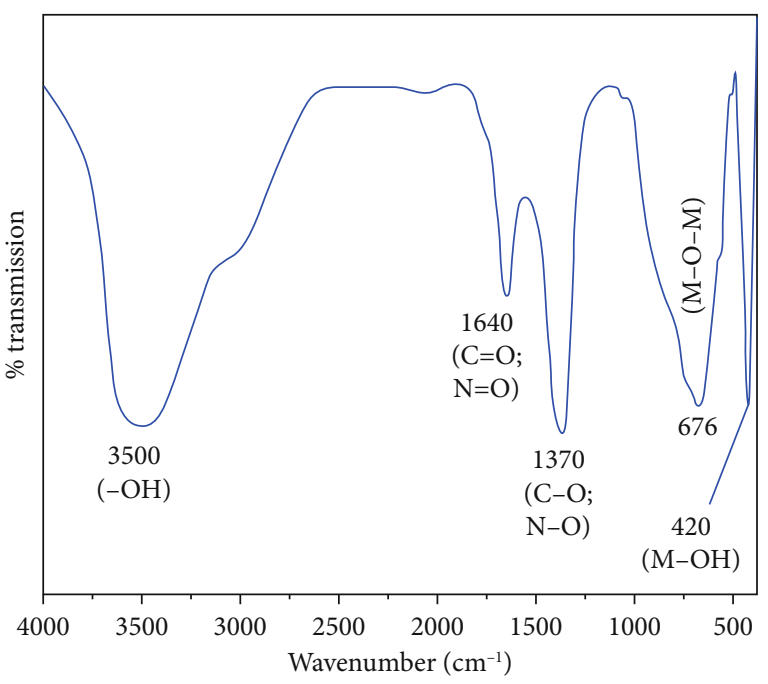

FIGURE 5: FTIR spectrum of the layered double hydroxides.

LDH (Figure 6). The zeta ( $\zeta$ ) potential values of LDH were positive, suggesting that the external surface of LDH was highly positively charged within the solution $\mathrm{pH}$ range from 3.0 to 12 . Similarly, Lee and coworkers [15] reported that the $\mathrm{pH}$ values of isoelectric point (IEP) of $\mathrm{Mg} / \mathrm{Al}-\mathrm{LDH}, \mathrm{LDH}$ calcinated at $400^{\circ} \mathrm{C}$, and $\mathrm{LDH}$ calcinated at $600^{\circ} \mathrm{C}$ were $12.1\left(\mathrm{pH}_{\mathrm{IEP}}\right), 12.7$, and 12.5 , respectively. An identical observation was summarized in a recent review article [6]. Furthermore, $\mathrm{LDH}$ had a high positive $\zeta$ value at $\mathrm{pH} 5.0$ $(42.5 \pm 3.5 \mathrm{mV})$ and $6.0(44.2 \pm 1.5 \mathrm{mV})$ which is consistent with the report of Abo El-Reesh and coworkers [10] for $\mathrm{Ni} / \mathrm{Fe}-\mathrm{LDH}(43.3 \mathrm{mV}$ at $\mathrm{pH} 6.0)$ and glycerol-modified $\mathrm{Ni} / \mathrm{Fe}-\mathrm{LDH}(32.8 \mathrm{mV}$ at $\mathrm{pH} 6)$. The result suggested that LDH exhibited a high affinity to anions in solution through electrostatic attraction.

Finally, as portrayed by SEM image (Figure 7), LDH exhibited a plate-like morphology on the surface. This is a typical morphology of synthesized LDH materials. As aforementioned in Section 1, the morphology of LDH strongly depended on the synthesis process and the nature of used metal salts. Different morphologies of LDH were observed in the literature such as the morphology like sheet [22], nanofoil [11], 3D hierarchically flower [12, 18], and interconnecting flower [20]. To some extent, the morphological property of LDH has a less impact on its adsorption capacity compared to the others (i.e., its surface area and charge).

3.2. Adsorption Isotherm. The adsorption isotherms of target potentially toxic metals onto LDH are presented in Figure 8. The $\mathrm{pH}$ solutions were maintained at around $5.0 \pm 0.2$ to avoid the precipitation in the form of metal hydroxide (also known as precipitation by $\mathrm{pH}$ ). For example, copper metal ions can be spontaneously precipitated in solution in the form of $\mathrm{Cu}(\mathrm{OH})_{2}$ without being adsorbed by $\mathrm{LDH}$ when solution $\mathrm{pH}$ values are higher than 6.0. Furthermore, in a low solution $\mathrm{pH}$ value (i.e., 2.0), the structure of the synthesis clay might not be stable. This is because the LDH particles were synthesized through the coprecipitation process at a high $\mathrm{pH}$ value of 12 (Section 2.1). In other words, the

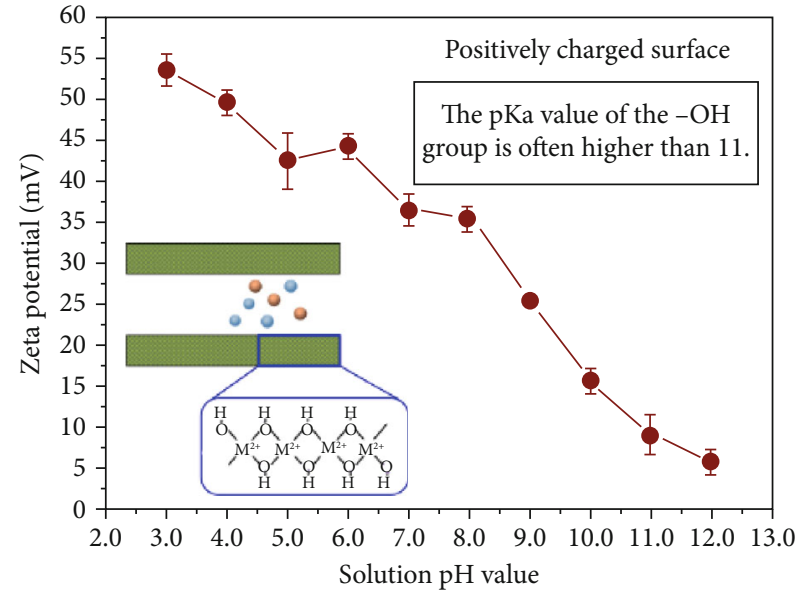

Figure 6: Zeta potential of the layered double hydroxides under different solution $\mathrm{pH}$.

synthesized particles had a low chemical stability under acidic solution.

According to the shape classification of adsorption isotherm [41], the shape of the adsorption isotherms of metal cations and oxyanions was categorized as L-type or F-type (not H-type) without a strict plateau. The relationship between isotherm parameters and isotherm shapes has been analyzed by Tran and coworkers [32]. The value of the $n$ parameter of the Freundlich model in Table 2 ranged from 0.203 to 0.446 (lower 1.0), suggesting that the adsorption isotherm was favorable. The conclusion was confirmed by the concave downward curve of adsorption isotherm in Figure 8. The outcome suggested that LDH tended to exhibit a higher affinity to the pollutants under high concentrations in solution. Therefore, it should be given a considerable concern when LDH is applied to remove the pollutants under their low concentrations (or trace levels) from the water environment.

The corresponding parameters of the Langmuir and Freundlich models (Table 2) were calculated from the nonlinear optimization method to minimize the error function during modeling. According to a higher adjusted coefficient of determination, the Langmuir model (Adj- $R^{2}=0.985$ 0.994) was more appropriate to describe the experimental data of equilibrium adsorption of the target metals by $\mathrm{LDH}$ than the Freundlich model (Adj- $R^{2}=0.853-0.962$ ) did. This conclusion is well consistent with the result of other statistics; for example, the value of $\chi^{2}, S D$, MPSD, and BIC of the Langmuir model was lower than that of the Freundlich model (Table 2). As expected, the prepared LDH can effectively adsorb cationic and oxyanionic metal ions in aqueous solutions. This means that it can serve as a promising dualelectronic adsorbent for removing both cationic and anionic pollutants from water media.

In general, the Freundlich model can be applied for estimating the maximum adsorption capacity of an adsorbent when adsorption shape is nearly linear (the $n$ parameter $\approx 1.0$ ). The linear isotherm shape is commonly known as the partition phenomenon [26]. In this study, the $n$ parameter was lower than 1.0 ; therefore, the 


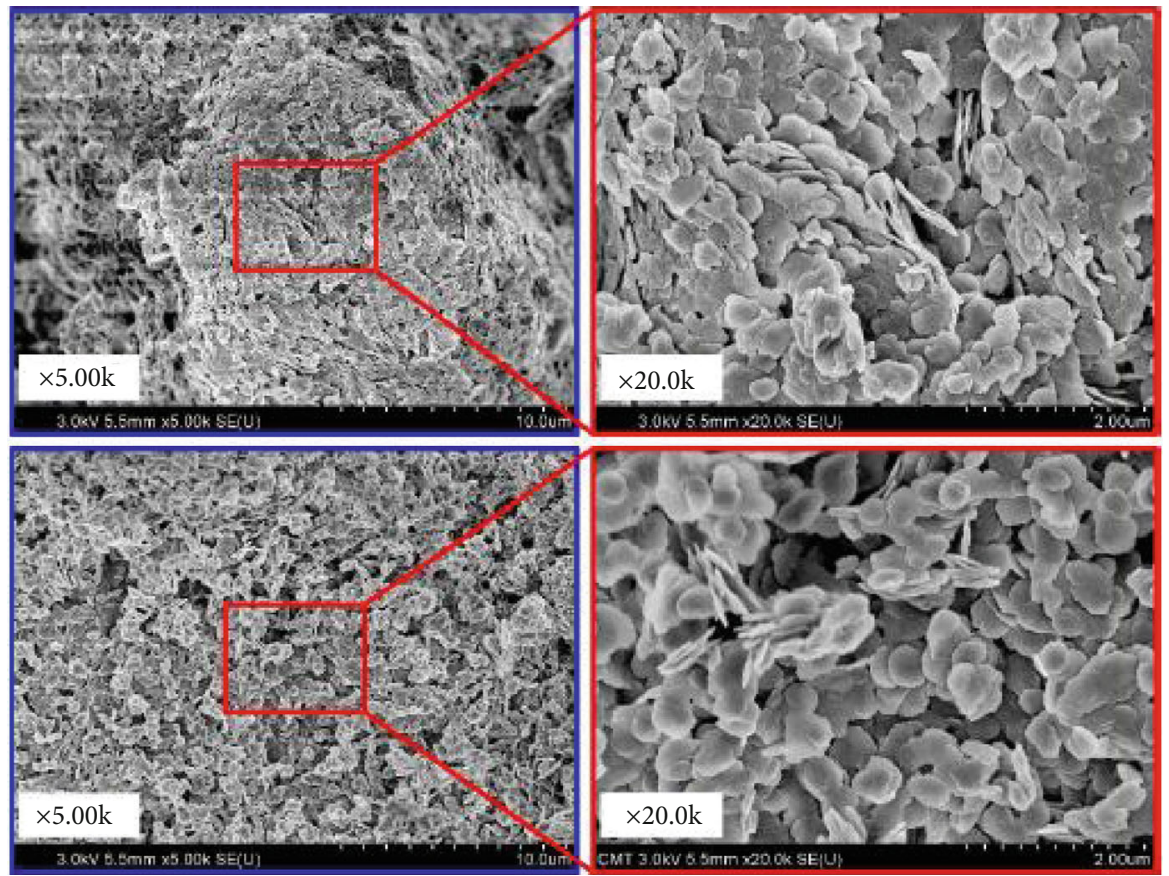

FIgURE 7: SEM image of the layered double hydroxides at different magnifications.

maximum adsorption capacity of $\mathrm{LDH}$ was estimated through the Langmuir model. Under the same operational conditions of adsorption study, the maximum adsorption capacity $\left(Q_{\max }^{o}\right)$ of $\mathrm{LDH}$ towards the potentially toxic metals exhibited the following order: $1.299 \mathrm{mmol} / \mathrm{g}$ (for $\mathrm{Ni}^{2+}$ adsorption) $>0.880 \mathrm{mmol} / \mathrm{g}$ $\left(\mathrm{Cd}^{2+}\right)>0.701 \mathrm{mmol} / \mathrm{g} \quad\left(\mathrm{Cr}^{3+}\right)>0.657 \mathrm{mmol} / \mathrm{g} \quad\left(\mathrm{Pb}^{2+}\right)>0.601$ $\mathrm{mmol} / \mathrm{g} \quad\left(\mathrm{Cu}^{2+}\right)>0.589 \mathrm{mmol} / \mathrm{g} \quad\left(\mathrm{Cr}_{2} \mathrm{O}_{7}^{2-}\right)>0.522 \mathrm{mmol} / \mathrm{g}$ $\left(\mathrm{MnO}_{4}{ }^{-}\right)$. The result suggested that $\mathrm{CO}_{3}-\mathrm{LDH}$ possessed a higher adsorption capacity of cationic metals than anionic ones in solution. This is because the precipitation mechanism between cationic metal ion in solution and $\mathrm{CO}_{3}{ }^{2-}$ anion in the interlayer region of $\mathrm{LDH}$ (i.e., $\mathrm{CdCO}_{3}$ ) was more dominant than anion exchange mechanism between anionic metal ion in solution and $\mathrm{CO}_{3}{ }^{2-}$ anion in $\mathrm{LDH}$. In addition, the cationic metal ions highly tended to react with the $-\mathrm{OH}$ groups on the external surface of LDH through nonelectrostatic attraction (inner-sphere complexation).

Because most LDH materials have applied for the removal of hexavalent chromium from water, such adsorbate was selected as a target pollutant for comparison. The $\mathrm{Mg} / \mathrm{Al}$ $\mathrm{LDH}$ adsorbent $\left(Q_{\max }^{\mathrm{o}}=127.3 \mathrm{mg} / \mathrm{g}\right)$ exhibited a higher adsorption capacity towards $\mathrm{Cr}(\mathrm{VI})$ that the other LDH materials reported in the literature, such as $\mathrm{Mg} / \mathrm{Al}-\mathrm{LDH}$ $(16.3 \mathrm{mg} / \mathrm{g})$ [42], Ni/Fe LDH $(50.4 \mathrm{mg} / \mathrm{g})$ [10], Mg/Al-LDH $(58.8 \mathrm{mg} / \mathrm{g})$ [37], and $\mathrm{Mg} / \mathrm{Al}-\mathrm{LDH}$ calcinated at $500^{\circ} \mathrm{C}$ $(65.2 \mathrm{mg} / \mathrm{g})$ [12]. Notably, a higher zeta potential value of $\mathrm{Mg} / \mathrm{Al}-\mathrm{LDH}(42.7 \mathrm{mV})$ in this study compared to that of $\mathrm{Mg} / \mathrm{Al}-\mathrm{LDH}(\sim 18 \mathrm{mV})$ reported by other researchers [37] might lead to a higher affinity to $\mathrm{Cr}(\mathrm{VI})$ in solution through electrostatic attraction. As a result, the prepared $\mathrm{Mg} / \mathrm{Al}-\mathrm{LDH}$ adsorbent $(127.3 \mathrm{mg} / \mathrm{g})$ exhibited a remarkably higher maximum adsorption capacity than the $\mathrm{Mg} / \mathrm{Al}-\mathrm{LDH}$ one $(58.8 \mathrm{mg} / \mathrm{g})$ reported by Zhu and colleagues [37]. Interestingly, the synthesized $\mathrm{Mg} / \mathrm{Al}-\mathrm{LDH}$ nanomaterial $\left(Q_{\max }^{\circ}=127.3\right.$ $\mathrm{mg} / \mathrm{g}$ ) possesses an outstanding adsorption capacity compared to activated carbon $(103 \mathrm{mg} / \mathrm{g})$ and biochar ( $83.5 \mathrm{mg} / \mathrm{g})$ [43], HDTMA-modified zeolite $(39.7 \mathrm{mg} / \mathrm{g})$ [26], and HDTMA-modified titanate nanotubes $(18.6 \mathrm{mg} / \mathrm{g})$ [27].

3.3. Feasible Adsorption Mechanism. In essence, the mechanism of pollutant adsorption is often strongly dependent on the solution $\mathrm{pH}$ value. This is because solution $\mathrm{pH}$ greatly affects both the species of adsorbate and the surface of adsorbent. In this study, potential adsorption mechanisms were discussed at the solution of $\mathrm{pH}_{\text {Equilibrium }}$ 5.0.

As shown in Figure 6, the prepared LDH adsorbent exhibited a positively charged surface because of its positive $\zeta$ value of $42.7 \mathrm{mV}$. Therefore, electrostatic attraction was ruled out for the adsorption of cationic metal ions, but the integral contribution to the adsorption of oxyanionic metal ions onto LDH. Furthermore, a previous study indicated that the abundant presence of $\mathrm{CO}_{3}^{2-}$ anions in the interlayer region of $\mathrm{LDH}$ can spontaneously simulate the precipitation process occurring between cationic metals (i.e., $\mathrm{Pb}^{2+}$ and $\left.\mathrm{Cu}^{2+}\right)$ and carbonate ions to form carbonate hydroxides (i.e., $\mathrm{Pb}_{3}(\mathrm{OH})_{2}\left(\mathrm{CO}_{3}\right)_{2}$ and $\mathrm{Cu}_{2} \mathrm{CO}_{3}(\mathrm{OH})_{2}$, respectively) [9, 24]. In addition, Rahman and coworkers [22] analyzed the precipitates (characterized by XRD) after the adsorption process of heavy metals $\left(\mathrm{Cu}^{2+}, \mathrm{Pb}^{2+}\right.$, and $\left.\mathrm{Zn}^{2+}\right)$ onto $\mathrm{LDH}$. They found the important role of host $\mathrm{NO}_{3}{ }^{2-}$ anions in the interlayer region of $\mathrm{Mg} / \mathrm{Al}-\mathrm{LDH}$ in removing potentially toxic metals. The formed precipitates after the adsorption process included copper nitrate hydroxide $\left[\mathrm{Cu}_{2}(\mathrm{OH})_{3} \mathrm{NO}_{3}\right]$, lead nitrate hydroxide $\left[\mathrm{Pb}_{4}(\mathrm{OH})_{4}\left(\mathrm{NO}_{3}\right)_{4}\right]$, zinc nitrate hydroxide hydrate $\left[\mathrm{Zn}\left(\mathrm{NO}_{3}\right)(\mathrm{OH}) \mathrm{H}_{2} \mathrm{O}\right]$, and zinc nitrate hydroxide $\left[\mathrm{Zn}_{5}\left(\mathrm{NO}_{3}\right)_{2}(\mathrm{OH})_{8}\right]$. In this study, the interlayer region of $\mathrm{Mg} / \mathrm{Al}-\mathrm{LDH}$ contained both the host $\mathrm{CO}_{3}{ }^{2-}$ and $\mathrm{NO}_{3}{ }^{-}$ anions. Therefore, it is expected that the precipitates in the 


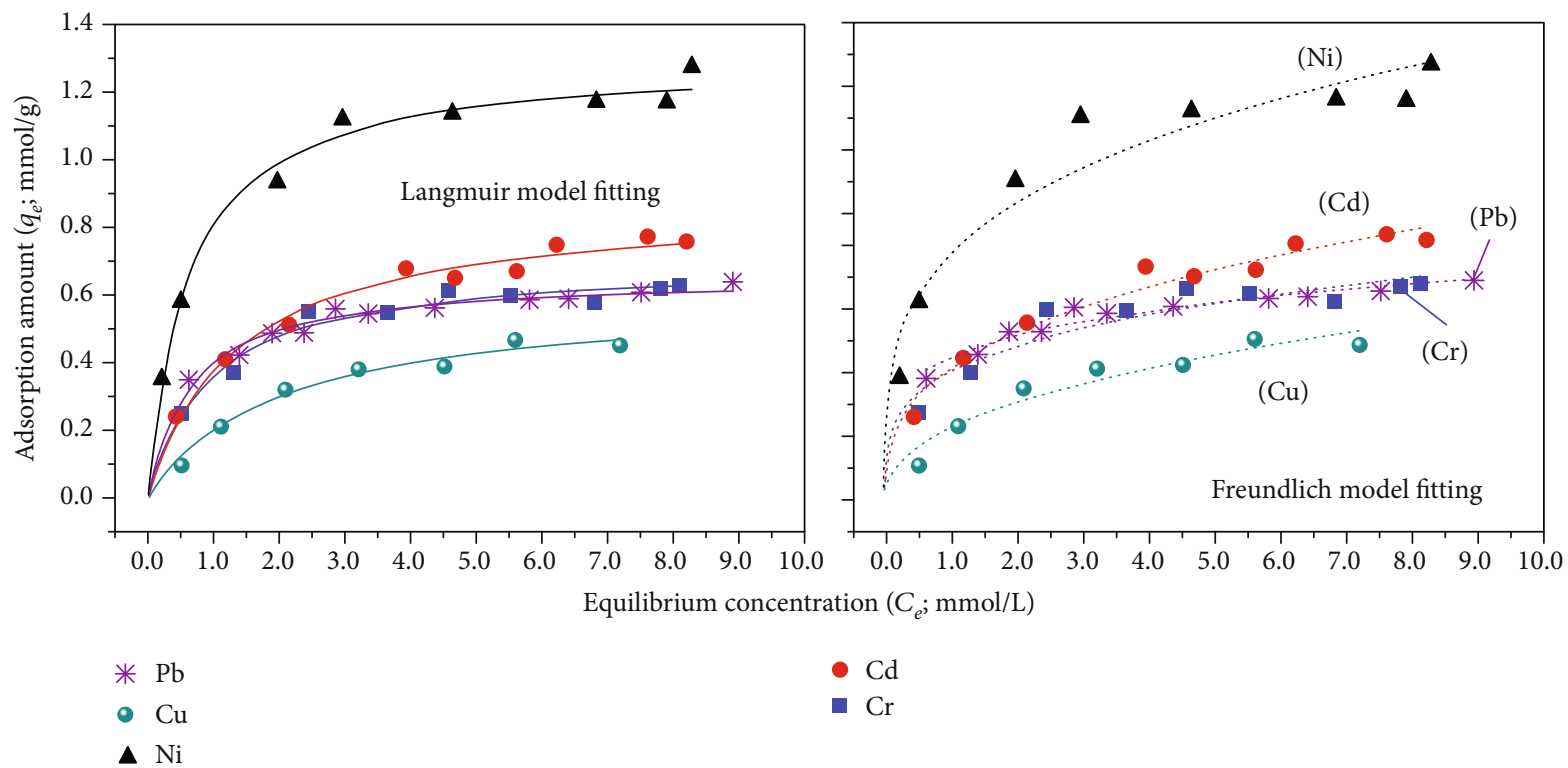

(a)

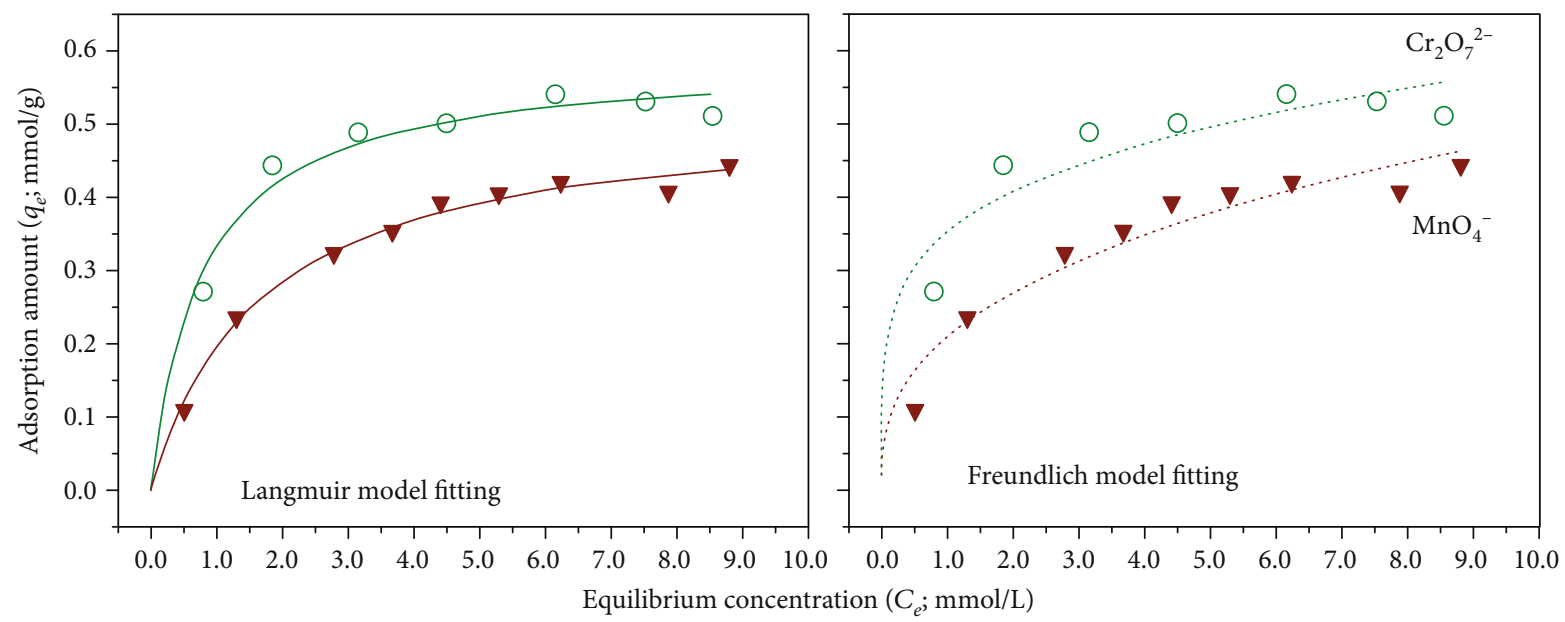

$\mathrm{O} \mathrm{Cr}_{2} \mathrm{O}_{7}^{2-}$

$\nabla \mathrm{MnO}_{4}^{-}$

(b)

FIgURE 8: Adsorption isotherm of (a) cationic metal ions and (b) oxyanionic metal ions onto the prepared LDH nanoparticles.

form of carbonate and nitrate were formed after the adsorption process. This mechanism might be dominant than the others (i.e., isomorphic substitution and complexation).

Notably, LDH abundantly contained the $-\mathrm{OH}$ group on its surface; such group can act as an active site to binding cationic metal ions in solution through surface complexation [5]. For example, Zhao and coworkers [20] applied the Xray photoelectron spectroscopy (XPS) spectrum of $\mathrm{Cu} 2 \mathrm{p}$ and $\mathrm{Zn} 2 \mathrm{p}$ and concluded that the surface complexation occurred between the $\mathrm{OH}$ groups on the external surface of $\mathrm{Li} / \mathrm{Al}-\mathrm{LDH}$ and $\mathrm{Cu}^{2+}$ or $\mathrm{Zn}^{2+}$ ions. An identical conclusion was obtained for the adsorption of $\mathrm{Pb}^{2+}$ ions onto $\mathrm{Mn} / \mathrm{Mg} / \mathrm{Fe}-\mathrm{LDH}$ [24], $\mathrm{Cu}^{2+}$ ions onto sulfonated calix[4]arene intercalated $\mathrm{Mg} / \mathrm{Al}-\mathrm{LDH}[21]$, and $\mathrm{Pb}^{2+}, \mathrm{Cu}^{2+}, \mathrm{Cd}^{2+}$, and $\mathrm{Zn}^{2+}$ onto sulfide-selector intercalated Ni/Fe-LDH [23]. Another feasible mechanism was isomorphic substitution.
Zhou and colleagues [24] found that the isomorphic substitution occurring between $\mathrm{Pb}^{2+}$ in solution and $\mathrm{Mg}^{2+}$ in the structure of $\mathrm{Mn} / \mathrm{Mg} / \mathrm{Fe}-\mathrm{LDH}$ played an integral role in adsorption mechanism. Isomorphic substitution has been recognized by some other scholars for the adsorption of potentially toxic metals onto $\mathrm{LDH}$-based materials [20].

In contrast, the adsorption process of $\mathrm{Cr}_{2} \mathrm{O}_{7}{ }^{2-}$ and $\mathrm{MnO}_{4}{ }^{-}$anions onto $\mathrm{LDH}$ might involve anion exchange between the oxyanions in the solution and the anions $\left(\mathrm{CO}_{3}{ }^{2-}\right.$ and $\left.\mathrm{NO}_{3}{ }^{-}\right)$in the interlayer region of $\mathrm{LDH}$. A similar conclusion was reported by other scholars for adsorption of $\mathrm{Cr}(\mathrm{VI})$ onto $\mathrm{Ni} / \mathrm{Fe}-\mathrm{LDH}$ [10], polyaniline-modified $\mathrm{Mg} / \mathrm{Al}-\mathrm{LDH}$ [37], in situ synthesized Mg/Al-LDH [13], anisotropic $\mathrm{Mg} / \mathrm{Al}-\mathrm{LDH}$ nanosheets [14], and threedimensional hierarchical flower-like Mg/Al-LDH [12]. Some detail information on the adsorption mechanism 
TABLE 2: The corresponding parameters of the Langmuir and Freundlich models.

\begin{tabular}{|c|c|c|c|c|c|c|c|c|}
\hline \multirow{2}{*}{ Unit } & & \multicolumn{5}{|c|}{ Cationic metals } & \multicolumn{2}{|c|}{ Anionic metals } \\
\hline & & $\mathrm{Cu}^{2+}$ & $\mathrm{Cd}^{2+}$ & $\mathrm{Ni}^{2+}$ & $\mathrm{Pb}^{2+}$ & $\mathrm{Cr}^{3+}$ & $\mathrm{Cr}_{2} \mathrm{O}_{7}{ }^{2-}$ & $\mathrm{MnO}_{4}^{-}$ \\
\hline \multicolumn{9}{|c|}{ (1) Langmuir model } \\
\hline$Q_{\max }^{o}$ & $\mathrm{mmol} / \mathrm{g}$ & 0.601 & 0.880 & 1.299 & 0.657 & 0.701 & 0.589 & 0.522 \\
\hline$K_{\mathrm{L}}$ & $\mathrm{L} / \mathrm{mmol}$ & 0.493 & 0.742 & 1.630 & 1.546 & 1.072 & 1.282 & 0.602 \\
\hline Adj- $R^{2}$ & - & 0.985 & 0.988 & 0.991 & 0.986 & 0.982 & 0.985 & 0.994 \\
\hline$\chi^{2}$ & $(\times 1000)$ & 0.428 & 0.766 & 1.760 & 0.410 & 0.761 & 0.508 & 0.143 \\
\hline SD & - & 0.023 & 0.030 & 0.045 & 0.021 & 0.030 & 0.025 & 0.013 \\
\hline MPSD & - & 4.41 & 3.86 & 4.68 & 2.85 & 4.14 & 3.84 & 2.31 \\
\hline BIC & - & -51.4 & -61.2 & -47.7 & -82.1 & -61.3 & -50.3 & -76.3 \\
\hline \multicolumn{9}{|c|}{ (2) Freundlich model } \\
\hline$K_{\mathrm{F}}$ & $(\mathrm{mmol} / \mathrm{g}) /(\mathrm{L} / \mathrm{mmol})^{n}$ & 0.205 & 0.384 & 0.724 & 0.414 & 0.371 & 0.351 & 0.209 \\
\hline$n$ & - & 0.446 & 0.347 & 0.270 & 0.203 & 0.271 & 0.215 & 0.366 \\
\hline Adj- $R^{2}$ & - & 0.953 & 0.983 & 0.961 & 0.937 & 0.949 & 0.950 & 0.959 \\
\hline$\chi^{2}$ & $(\times 1000)$ & 1.390 & 1.120 & 7.730 & 0.477 & 2.220 & 1.740 & 0.882 \\
\hline SD & - & 0.041 & 0.036 & 0.095 & 0.022 & 0.050 & 0.046 & 0.032 \\
\hline MPSD & - & 5.26 & 4.14 & 8.09 & 3.17 & 6.29 & 5.16 & 3.94 \\
\hline $\mathrm{BIC}$ & - & -43.3 & -57.8 & -35.8 & -81.5 & -51.6 & -41.7 & -60.0 \\
\hline
\end{tabular}

related to anionic exchange has been reported by Goh and coworkers [7]. Lastly, the mechanism of adsorptioncoupled reduction has been identified during the process of $\mathrm{Cr}(\mathrm{VI})$ adsorption onto LDH-based materials. More detail information on such mechanism has been recently reviewed by Tran and colleagues [6].

\section{Conclusions}

The layered double hydroxide-based nanoadsorbent was successfully and rapidly synthesized from two low-cost metal salts of $\mathrm{Mg}\left(\mathrm{NO}_{3}\right)_{2}$ and $\mathrm{Al}\left(\mathrm{NO}_{3}\right)_{3}$ through the simple coprecipitation method. The basal spacing of LDH was $0.773 \mathrm{~nm}$. LDH was nonporous material, with $S_{\text {BET }}$ and $V_{\text {Total }}$ being $23.2 \mathrm{~m}^{2} / \mathrm{g}$ and $0.161 \mathrm{~cm}^{3} / \mathrm{g}$, respectively. The surface charge of $\mathrm{LDH}$ was positive within solution $\mathrm{pH}$ from 3.0 to 12 . The $\mathrm{CO}_{3}{ }^{2-}$ and $\mathrm{NO}_{3}{ }^{-}$anions existed abundantly in the interlayer region of $\mathrm{LDH}$.

The Langmuir maximum adsorption capacity $\left(Q_{\max }^{o} \pm\right.$ standard deviation) of $\mathrm{LDH}$ towards various target toxic metals followed the decreasing order: $\mathrm{Ni}^{2+}(1.299 \pm$ $0.029 \mathrm{mmol} / \mathrm{g})>\mathrm{Cd}^{2+}(0.880 \pm 0.028 \mathrm{mmol} / \mathrm{g})>\mathrm{Cr}^{3+}(0.701 \pm$ $0.023 \mathrm{mmol} / \mathrm{g})>\mathrm{Pb}^{2+}(0.657 \pm 0.014 \mathrm{mmol} / \mathrm{g})>\mathrm{Cu}^{2+}(0.601 \pm$ $0.038 \mathrm{mmol} / \mathrm{g})>\mathrm{Cr}_{2} \mathrm{O}_{7}{ }^{2-} \quad(0.589 \pm 0.038 \mathrm{mmol} / \mathrm{g})>\mathrm{MnO}_{4}{ }^{-}$ $(0.522 \pm 0.015 \mathrm{mmol} / \mathrm{g})$. It can be experimentally concluded that $\mathrm{LDH}$ was a promising dual-electronic adsorbent for effectively removing both toxic metal oxyanions and cations from the water environment. However, some further studies should be continued to feasibly apply this material for commercial purposes and real water treatment. They include the studies of adsorption column, regeneration, cost estimation, and toxicity.

\section{Data Availability}

No data were used to support this study.

\section{Conflicts of Interest}

The authors declare that they have no conflicts of interest.

\section{Acknowledgments}

This research is funded by Vietnam National Foundation for Science and Technology Development (NAFOSTED) under grant number 103.02-2019.54.

\section{References}

[1] F.-C. Huang, C.-K. Lee, Y.-L. Han, W.-C. Chao, and H.P. Chao, "Preparation of activated carbon using micro-nano carbon spheres through chemical activation," Journal of the Taiwan Institute of Chemical Engineers, vol. 45, no. 5, pp. 2805-2812, 2014.

[2] S. Wong, N. Ngadi, I. M. Inuwa, and O. Hassan, "Recent advances in applications of activated carbon from biowaste for wastewater treatment: a short review," Journal of Cleaner Production, vol. 175, pp. 361-375, 2018.

[3] H. N. Tran, S.-J. You, and H.-P. Chao, "Fast and efficient adsorption of methylene green 5 on activated carbon prepared from new chemical activation method," Journal of Environmental Management, vol. 188, pp. 322-336, 2017.

[4] F. Tomul, Y. Arslan, B. Kabak et al., "Peanut shells-derived biochars prepared from different carbonization processes: comparison of characterization and mechanism of naproxen adsorption in water," Science of The Total Environment, vol. 726, article 137828, 2020. 
[5] X. Liang, Y. Zang, Y. Xu et al., "Sorption of metal cations on layered double hydroxides," Colloids and Surfaces A: Physicochemical and Engineering Aspects, vol. 433, pp. 122-131, 2013.

[6] H. N. Tran, D. T. Nguyen, G. T. Le et al., "Adsorption mechanism of hexavalent chromium onto layered double hydroxides- based adsorbents: A systematic in-depth review," Journal of Hazardous Materials, vol. 373, pp. 258-270, 2019.

[7] K.-H. Goh, T.-T. Lim, and Z. Dong, "Application of layered double hydroxides for removal of oxyanions: a review," Water Research, vol. 42, no. 6-7, pp. 1343-1368, 2008.

[8] J. He, M. Wei, B. Li, Y. Kang, D. G. Evans, and X. Duan, "Preparation of layered double hydroxides," in Layered Double Hydroxides, X. Duan and D. G. Evans, Eds., pp. 89-119, Springer, 2006.

[9] S.-T. Lin, H. N. Tran, H.-P. Chao, and J.-F. Lee, "Layered double hydroxides intercalated with sulfur-containing organic solutes for efficient removal of cationic and oxyanionic metal ions," Applied Clay Science, vol. 162, pp. 443-453, 2018.

[10] G. Y. Abo El-Reesh, A. A. Farghali, M. Taha, and R. K. Mahmoud, "Novel synthesis of Ni/Fe layered double hydroxides using urea and glycerol and their enhanced adsorption behavior for Cr(VI) removal," Scientific Reports, vol. 10, no. 1, p. 587, 2020.

[11] M. Chakraborty, S. Dasgupta, C. Soundrapandian et al., "Methotrexate intercalated ZnAl-layered double hydroxide," Journal of Solid State Chemistry, vol. 184, no. 9, pp. 24392445, 2011.

[12] X.-Y. Yu, T. Luo, Y. Jia et al., “Three-dimensional hierarchical flower-like Mg-Al-layered double hydroxides: highly efficient adsorbents for As (V) and Cr(VI) removal,", Nanoscale, vol. 4, no. 11, pp. 3466-3474, 2012.

[13] H.-P. Chao, Y.-C. Wang, and H. N. Tran, "Removal of hexavalent chromium from groundwater by $\mathrm{Mg} / \mathrm{Al}$-layered double hydroxides using characteristics of in-situ synthesis," Environmental Pollution, vol. 243, pp. 620-629, 2018.

[14] H. Wang, S. Wang, Z. Chen, X. Zhou, J. Wang, and Z. Chen, "Engineered biochar with anisotropic layered double hydroxide nanosheets to simultaneously and efficiently capture $\mathrm{Pb}^{2+}$ and $\mathrm{CrO}_{4}{ }^{2-}$ from electroplating wastewater," Bioresource Technology, vol. 306, article 123118, 2020.

[15] S.-H. Lee, M. Tanaka, Y. Takahashi, and K.-W. Kim, "Enhanced adsorption of arsenate and antimonate by calcined $\mathrm{Mg} / \mathrm{Al}$ layered double hydroxide: investigation of comparative adsorption mechanism by surface characterization," Chemosphere, vol. 211, pp. 903-911, 2018.

[16] M. T. Rahman, T. Kameda, T. Miura, S. Kumagai, and T. Yoshioka, "Application of $\mathrm{Mg}-\mathrm{Al}$ layered double hydroxide for treating acidic mine wastewater: a novel approach to sludge reduction," Chemistry and Ecology, vol. 35, no. 2, pp. 128-142, 2018.

[17] N. Ouasfi, M. Zbair, E. M. Sabbar, and L. Khamliche, "High performance of $\mathrm{Zn}-\mathrm{Al}-\mathrm{CO}_{3}$ layered double hydroxide for anionic reactive blue 21 dye adsorption: kinetic, equilibrium, and thermodynamic studies," Nanotechnology for Environmental Engineering, vol. 4, no. 1, p. 16, 2019.

[18] Z. Zhu, S. Ouyang, P. Li, L. Shan, R. Ma, and P. Zhang, "Persistent organic pollutants removal via hierarchical flower-like layered double hydroxide: adsorption behaviors and mechanism investigation," Applied Clay Science, vol. 188, p. 105500, 2020 .
[19] M. Shamsayei, Y. Yamini, and H. Asiabi, "Fabrication of zwitterionic histidine/layered double hydroxide hybrid nanosheets for highly efficient and fast removal of anionic dyes," Journal of Colloid and Interface Science, vol. 529, pp. 255-264, 2018.

[20] L.-X. Zhao, J.-L. Liang, N. Li, H. Xiao, L.-Z. Chen, and R.S. Zhao, "Kinetic, thermodynamic and isotherm investigations of $\mathrm{Cu}^{2+}$ and $\mathrm{Zn}^{2+}$ adsorption on LiAl hydrotalcite-like compound," Science of The Total Environment, vol. 716, article 137120, 2020.

[21] A. T. Reda and D. Zhang, "Sorption of metal ions from aqueous solution by sulfonated calix[4]arene intercalated with layered double hydroxide," Journal of Environmental Chemical Engineering, vol. 7, no. 2, article 103021, 2019.

[22] M. T. Rahman, T. Kameda, S. Kumagai, and T. Yoshioka, "Effectiveness of Mg-Al-layered double hydroxide for heavy metal removal from mine wastewater and sludge volume reduction," International journal of Environmental Science and Technology, vol. 15, no. 2, pp. 263-272, 2018.

[23] J. Wang, L. Zhang, T. Zhang et al., "Selective removal of heavy metal ions in aqueous solutions by sulfide-selector intercalated layered double hydroxide adsorbent," Journal of Materials Science \& Technology, vol. 35, no. 9, pp. 1809-1816, 2019.

[24] H. Zhou, Z. Jiang, and S. Wei, "A new hydrotalcite-like absorbent FeMnMg-LDH and its adsorption capacity for $\mathrm{Pb}^{2}{ }^{+}$ions in water," Applied Clay Science, vol. 153, pp. 29-37, 2018.

[25] Y. Xu, Y. Ding, J. Wang et al., "In-situ synthesis of calcium aluminum layered double hydroxides for advanced treatment of leachate biochemical tail water," Science of The Total Environment, vol. 701, article 134891, 2020.

[26] H.-P. Chao and S.-H. Chen, "Adsorption characteristics of both cationic and oxyanionic metal ions on hexadecyltrimethylammonium bromide-modified NaY zeolite," Chemical Engineering Journal, vol. 193-194, pp. 283-289, 2012.

[27] H.-P. Chao, C.-K. Lee, L.-C. Juang, and Y.-L. Han, "Sorption of organic compounds, oxyanions, and heavy metal ions on surfactant modified titanate nanotubes," Industrial \& Engineering Chemistry Research, vol. 52, no. 29, pp. 9843-9850, 2013.

[28] F. Chen, M. Hong, W. You, C. Li, and Y. Yu, "Simultaneous efficient adsorption of $\mathrm{Pb}^{2+}$ and $\mathrm{MnO}_{4}^{-}$ions by MCM-41 functionalized with amine and nitrilotriacetic acid anhydride," Applied Surface Science, vol. 357, pp. 856-865, 2015.

[29] W. T. Reichle, "Catalytic reactions by thermally activated, synthetic, anionic clay minerals," Journal of Catalysis, vol. 94, no. 2, pp. 547-557, 1985.

[30] I. Langmuir, "The adsorption of gases on plane surfaces of glass, mica and platinum," Journal of the American Chemical Society, vol. 40, no. 9, pp. 1361-1403, 1918.

[31] H. Freundlich, "Über die Adsorption in Lösungen," Zeitschrift für Physikalische Chemie, vol. 57U, no. 1, pp. 385-470, 1907.

[32] H. N. Tran, S.-J. You, A. Hosseini-Bandegharaei, and H.P. Chao, "Mistakes and inconsistencies regarding adsorption of contaminants from aqueous solutions: a critical review," Water Research, vol. 120, pp. 88-116, 2017.

[33] M. Kamari, S. Shafiee, F. Salimi, and C. Karami, "Comparison of modified boehmite nanoplatelets and nanowires for dye removal from aqueous solution," Desalination and Water Treatment, vol. 161, pp. 304-314, 2019.

[34] D. W. Marquardt, "An algorithm for least-squares estimation of nonlinear parameters," Journal of the Society for Industrial and Applied Mathematics, vol. 11, no. 2, pp. 431-441, 1963. 
[35] G. Schwarz, "Estimating the dimension of a model," The Annals of Statistics, vol. 6, no. 2, pp. 461-464, 1978.

[36] C. Lei, X. Zhu, B. Zhu, C. Jiang, Y. Le, and J. Yu, "Superb adsorption capacity of hierarchical calcined $\mathrm{Ni} / \mathrm{Mg} / \mathrm{Al}$ layered double hydroxides for Congo red and Cr(VI) ions," Journal of Hazardous Materials, vol. 321, pp. 801-811, 2017.

[37] K. Zhu, Y. Gao, X. Tan, and C. Chen, "Polyaniline-modified $\mathrm{Mg} / \mathrm{Al}$ layered double hydroxide composites and their application in efficient removal of $\mathrm{Cr}(\mathrm{VI})$," ACS Sustainable Chemistry \& Engineering, vol. 4, no. 8, pp. 4361-4369, 2016.

[38] M. Thommes, K. Kaneko, A. V. Neimark et al., "Physisorption of gases, with special reference to the evaluation of surface area and pore size distribution (IUPAC Technical Report)," Pure and Applied Chemistry, vol. 87, no. 9-10, pp. 1051-1069, 2015.

[39] F. R. Costa, A. Leuteritz, U. Wagenknecht, D. Jehnichen, L. Häußler, and G. Heinrich, "Intercalation of $\mathrm{Mg}-\mathrm{Al}$ layered double hydroxide by anionic surfactants: preparation and characterization," Applied Clay Science, vol. 38, no. 3-4, pp. 153-164, 2008.

[40] W. Kagunya and W. Jones, "Aldol condensation of acetaldehyde using calcined layered double hydroxides," Applied Clay Science, vol. 10, no. 1-2, pp. 95-102, 1995.

[41] C. Moreno-Castilla, "Adsorption of organic molecules from aqueous solutions on carbon materials," Carbon, vol. 42, no. 1, pp. 83-94, 2004.

[42] S. Mechler, "Covid-19 pandemic: Face mask disinfection and sterilization for viruses," 2020, https://consteril.com/covid19-pandemic-disinfection-and-sterilization-of-face-masksfor-viruses/.

[43] A. T. Vo, V. P. Nguyen, A. Ouakouak et al., "Efficient removal of $\mathrm{Cr}(\mathrm{VI})$ from water by biochar and activated carbon prepared through hydrothermal carbonization and pyrolysis: adsorption-coupled reduction mechanism," Water, vol. 11, no. 6, pp. 1164-1178, 2019. 